\title{
Disease surveillance of Atlantic herring: molecular characterization of hepatic coccidiosis and a morphological report of a novel intestinal coccidian
}

\author{
Sarah E. Friend ${ }^{1}{ }$ Jan Lovy ${ }^{1, *}$, Paul K. Hershberger ${ }^{2}$ \\ ${ }^{1}$ New Jersey Division of Fish and Wildlife, Office of Fish and Wildlife Health and Forensics, 605 Pequest Road, Oxford, \\ New Jersey 07863, USA \\ ${ }^{2}$ US Geological Survey, Western Fisheries Research Center, Marrowstone Marine Field Station, \\ 616 Marrowstone Point Road, Nordland, Washington 98358, USA
}

\begin{abstract}
Surveillance for pathogens of Atlantic herring, including viral hemorrhagic septicemia virus (VHSV), Ichthyophonus hoferi, and hepatic and intestinal coccidians, was conducted from 2012 to 2016 in the NW Atlantic Ocean, New Jersey, USA. Neither VHSV nor I. hoferi was detected in any sample. Goussia clupearum was found in the livers of 40 to $78 \%$ of adult herring in varying parasite loads; however, associated pathological changes were negligible. Phylogenetic analysis based on small subunit 18S rRNA gene sequences placed G. clupearum most closely with other extraintestinal liver coccidia from the genus Calyptospora, though the G. clupearum isolates had a unique nucleotide insertion between 604 and 729 bp that did not occur in any other coccidian species. G. clupearum oocysts from Atlantic and Pacific herring were morphologically similar, though differences occurred in oocyst dimensions. Comparison of G. clupearum genetic sequences from Atlantic and Pacific herring revealed 4 nucleotide substitutions and 2 gaps in a $1749 \mathrm{bp}$ region, indicating some divergence in the geographically separate populations. Pacific $G$. clupearum oocysts were not directly infective, suggesting that a heteroxenous life cycle is likely. Intestinal coccidiosis was described for the first time from juvenile and adult Atlantic herring. A novel intestinal coccidian species was detected based on morphological characteristics of exogenously sporulated oocysts. A unique feature in these oocysts was the presence of 3 long (15.1 \pm $5.1 \mu \mathrm{m}$, mean $\pm \mathrm{SD}$ ) spiny projections on both ends of the oocyst. The novel morphology of this coccidian led us to tentatively name this parasite G. echinata n. sp.
\end{abstract}

KEY WORDS: Atlantic herring · Clupea harengus $\cdot$ Coccidiosis $\cdot$ Goussia clupearum $\cdot$ Goussia echinata

\section{INTRODUCTION}

The Atlantic herring Clupea harengus is an economically and ecologically important species, with populations ranging from the subarctic to temperate zones of the Atlantic Ocean. This migratory species is present in New Jersey waters in the winter and early spring, retreating to spawning grounds in the Gulf of Maine and Georges Bank during the summer and fall (Hay et al. 2001). Atlantic herring juveniles can also be sporadically found in New Jersey coastal waters throughout the summers, based on New Jersey Division of Fish and Wildlife (NJDFW) ocean trawl and Delaware Bay trawl survey results (unpubl.). Herring are primarily planktivores and represent a significant source of forage for marine mammals, sea birds, and large predatory fish. As such, they play a vital role in the transferring of nutrients to higher trophic levels. Additionally, the Atlantic herring is an important commercial species, representing the fifth largest marine fishery by weight worldwide, with over 1.8 million tons harvested in 2012 (FAO 2014). Though 
current populations appear stable, large population declines in the 1970s, largely attributed to overfishing, led to stock collapses across the Atlantic, with some areas experiencing declines greater than $98 \%$ (Melvin \& Stephenson 2007, Dickey-Collas et al. 2010, Richardson et al. 2011). The scale of the declines and slow recovery in some areas indicate that other factors may be involved in the historic fisheries collapses observed in the 1970s (Richardson et al. 2011). The apparent vulnerability of Atlantic herring to population declines highlights the need to identify factors influencing population dynamics. Though overfishing likely exerts the greatest pressure, other factors such as disease should be considered for understanding the biology of this species.

The impacts of diseases and parasites in clupeid species have been a focus of study in some populations. Two pathogens, viral hemorrhagic septicemia virus (VHSV) and Ichthyophonus hoferi, a fungal-like protist belonging to the class Mesomycetozoea, are of particular concern in both Atlantic and Pacific herring populations. Both VHSV and I. hoferi have been implicated as major causes of mortality in Pacific herring C. pallasii following stock collapse in Prince William Sound, Alaska, USA, after the 'Exxon Valdez' oil spill (Marty et al. 1998, 2010). Though many species of fish are known to be susceptible to VHSV, the 4 genotypes (I to IV) do exhibit some degree of host and geographic specificity (Einer-Jensen et al. 2004, Skall et al. 2005, Emmenegger et al. 2013). VHSV types I to III are considered endemic in Europe, affecting both marine and freshwater fish (Einer-Jensen et al. 2004, Pierce \& Stepien 2012), with genotype Ib found at a relatively high prevalence in Atlantic herring from the Norwegian spring-spawning stock (Johansen et al. 2013). In North America, genotype IVa was first detected in the Pacific Northwest in 1988 in cultured salmon, though now it has been isolated from various marine fish species (Meyers \& Winton 1995, Pierce \& Stepien 2012), including Pacific herring (Meyers et al. 1994, Meyers \& Winton 1995, Marty et al. 1998). In 2005, VHSV was isolated during an epizootic event from fish in Lake Ontario and later determined to be a novel genotype, IVb (Elsayed et al. 2006). Later testing revealed strain IVb was present in fish across the Great Lakes. Genotype IVc, found in brackish water fishes from the Atlantic coastal regions of Canada (Gagné et al. 2007), is lesser known, and information is lacking on its prevalence and impacts to marine fish, including herring in the western Atlantic Ocean. Though viral hemorrhagic septicemia has not been found in New Jersey waters, the known susceptibility and migratory life history of Atlantic herring make them a possible reservoir of the virus. Likewise, infection by I. hoferi, which stimulates granulomatous inflammation with necrosis in multiple organs, contributes to mortality and population declines in both Atlantic and Pacific herring. Multiple mass mortality events attributed to $I$. hoferi have been reported in Atlantic herring from both sides of the North Atlantic (Sindermann \& Chenoweth 1993, Rahimian \& Thulin 1996, Mellergaard \& Spanggaard 1997). Several of these epizootics have been associated with steep declines in landings of Atlantic herring (Sindermann 1990, Rahimian \& Thulin 1996, Mellergaard \& Spanggaard 1997, Burge et al. 2014). Given the economic and ecological importance of Atlantic herring, as well as the known susceptibility of this species to VHSV and I. hoferi, disease surveillance is important for assessing potential threats to herring populations. An intention of the present study was to determine if these pathogens could be detected off the coast of New Jersey.

A group of apicomplexan parasites, the coccidia, are known to cause both intestinal and extraintestinal infections in marine and freshwater fish. Despite being common parasites of teleosts, little information is available on their biology and diversity and the severity of infection in fish hosts. Because coccidiosis is often assumed to cause little pathology in wild fish, the impacts of intestinal and extraintestinal infections may be grossly underestimated (Dyková \& Lom 1981). Observations of mortalities caused by coccidiosis may be more common in cultured fish; Goussia kuehae was implicated as the cause for mortality in cultured Asian bass Lates calcarifer (Gibson-Kueh et al. 2011, Székely et al. 2013), and Cryptosporidium molnari causes severe lesions and mortality in cultured gilthead sea bream Sparus aurata (Alvarez-Pellitero \& Sitjà-Bobadilla 2002, Sitjà-Bobadilla \& Alvarez-Pellitero 2003). However, coccidian infections have been reported to reduce body condition (Morrison \& Hawkins 1984, Abollo et al. 2001) and cause heavy infections in wild fish populations (Abollo et al. 2001, Lovy \& Friend 2015). Reports of coccidia in Atlantic herring are limited to G. clupearum from the liver and Eimeria sardinae, which infects the testes (Morrison \& Hawkins 1984, MacKenzie 1987, Morrison \& Marryatt 1990). Though neither of these parasites is considered a serious pathogen of herring, both can elicit well-developed innate immune responses; this is reported to be more pronounced in G. clupearum infections, where phagocytes may occur in large numbers (Morrison \& Hawkins 1984). Intestinal coccidiosis is unknown from Atlantic herring, though an undescribed coccidian species from the pyloric cecum of Pacific herring has been reported by histology (Marty et al. 
$1998,2010)$. Although the prevalence of this intestinal coccidian was high, up to $100 \%$ in some populations (Marty et al. 2010), infection intensity was low, with no associated inflammation or lesions (Marty et al. 1998). Intestinal coccidiosis by $G$. ameliae has been described in another clupeid, the alewife Alosa pseudoharengus, at high prevalence (up to $92 \%$ in some populations) and with heavy infections associated with epithelial necrosis and sloughing of intestinal cells (Lovy \& Friend 2015).

With information on intestinal coccidiosis in Atlantic herring lacking, an intention of the present study was to document and describe intestinal coccidians present in this species. Additionally, though G. clupearum is unlikely to cause population level declines, its common occurrence in the livers of Atlantic and Pacific herring, as much as $89 \%$ reported in some populations of Atlantic herring (Morrison \& Hawkins 1984) and $84 \%$ in Pacific herring (Marty et al. 2010), as well as reports of hepatic histopathological changes (Costa \& MacKenzie 1994), led us to provide a more thorough assessment of G. clupearum in Atlantic herring from New Jersey, USA. Additional objectives included assessing morphologic and molecular differences between G. clupearum from Atlantic and Pacific herring, determining the phylogenetic placement of this parasite in relation to other coccidians, and assessing the infectivity of G. clupearum isolates to Pacific herring.

\section{MATERIALS AND METHODS}

\section{Fish collection and sampling}

Juvenile Atlantic herring were collected in October 2012 from the Delaware Bay Juvenile Finfish Trawl
Survey conducted by the Bureau of Marine Fisheries, NJDFW (project led by B. Neilan and J. Hearon). Briefly, fish were collected by $(\sim 5 \mathrm{~m}) 16 \mathrm{ft}$ otter trawl towed for 10 min behind a $42 \mathrm{ft}(\sim 13 \mathrm{~m})$ research vessel, the R/V 'Zephyrus'. Fish were dissected and fixed in $10 \%$ neutral-buffered formalin (NBF) in the field and transported back to the Fish Pathology Laboratory in Oxford, New Jersey, for routine histological processing (Table 1).

Adult Atlantic herring (total length $25.0 \pm 2.1 \mathrm{~cm}$, mean $\pm \mathrm{SD}$ ) were collected aboard the R/V 'Seawolf' from waters off the coast of New Jersey as part of an ongoing Ocean Stock Assessment project conducted by the Bureau of Marine Fisheries, NJDFW (project led by G. Hinks and L. Barry). Briefly, fish were collected by $30 \mathrm{~m}$ otter trawl towed behind the vessel. Fish were stored on ice and transported from the port at Point Pleasant, New Jersey, to the Fish Pathology Laboratory in Oxford, New Jersey, in the evening and either refrigerated $\left(4^{\circ} \mathrm{C}\right)$ for next-day processing or frozen $\left(-20\right.$ to $\left.-80^{\circ} \mathrm{C}\right)$ for future virology sampling. Sampling dates and details are provided in Table 1.

\section{Histopathology}

Internal organs including the gastrointestinal tract were collected from 10 juvenile Atlantic herring and fixed in $10 \%$ NBF in October 2012. Livers, hearts, and internal viscera from adult Atlantic herring were collected and fixed in 10\% NBF from 2013 to 2015 (Table 1). Tissues were routinely processed for histology and embedded in paraffin wax, and $4 \mu \mathrm{m}$ sections were cut and stained with hematoxylin and eosin. For surveillance of Ichthyophonus, heart tissue was cut in half and embedded in wax, and 2 serial

Table 1. Atlantic herring sampling details from 2012 to 2016 . Histo.: routine histological processing; NBF: neutral-buffered formalin; C.C.: cell culture on Epithelioma papulosum cyprinid cells; RT-PCR: real-time reverse transcription polymerase chain reaction

\begin{tabular}{|c|c|c|c|c|c|c|}
\hline Date & No. of samples & Testing method & Storage condition & Organs sampled & Age & Location \\
\hline Oct 2012 & 10 & Histo. & NBF & Internal viscera & Juvenile & Delaware Bay \\
\hline Apr 2013 & $\begin{array}{c}160 \\
40\end{array}$ & $\begin{array}{l}\text { C.C. } \\
\text { Histo. }\end{array}$ & $\begin{array}{l}-20^{\circ} \mathrm{C} \\
\mathrm{NBF}\end{array}$ & $\begin{array}{l}\text { Brain, spleen, kidney } \\
\text { Liver, heart }\end{array}$ & Adult & Atlantic Ocean \\
\hline Jan 2014 & $\begin{array}{c}120 \\
60 \\
60\end{array}$ & $\begin{array}{l}\text { C.C. } \\
\text { RT-PCR } \\
\text { Histo. }\end{array}$ & $\begin{array}{l}-80^{\circ} \mathrm{C} \\
-80^{\circ} \mathrm{C} \\
\mathrm{NBF}\end{array}$ & $\begin{array}{c}\text { Brain, spleen, kidney } \\
\text { Brain, kidney } \\
\text { Heart }\end{array}$ & Adult & Atlantic Ocean \\
\hline Jan 2015 & $\begin{array}{c}120 \\
60 \\
20\end{array}$ & $\begin{array}{c}\text { C.C./RT-PCR } \\
\text { Histo. } \\
\text { Histo. }\end{array}$ & $\begin{array}{l}-80^{\circ} \mathrm{C} \\
\mathrm{NBF} \\
\mathrm{NBF}\end{array}$ & $\begin{array}{l}\text { Brain, kidney } \\
\text { Heart } \\
\text { Liver }\end{array}$ & Adult & Atlantic Ocean \\
\hline May 2015 & $\begin{array}{c}4 \\
20\end{array}$ & $\begin{array}{c}\text { C.C./RT-PCR } \\
\text { Histo. }\end{array}$ & $\begin{array}{l}4^{\circ} \mathrm{C} \\
\mathrm{NBF}\end{array}$ & $\begin{array}{l}\text { Brain, kidney, gills } \\
\text { Internal viscera }\end{array}$ & Adult & Atlantic Ocean \\
\hline Jan 2016 & 120 & C.C./RT-PCR & $-40^{\circ} \mathrm{C}$ & Brain, kidney, gills & Adult & Atlantic Ocean \\
\hline
\end{tabular}


sections about $100 \mu \mathrm{m}$ apart were examined with a Nikon Eclipse E600 light microscope for the presence of schizonts or other stages of the parasite. For surveillance of coccidian infections, liver tissue was examined for the presence of Goussia clupearum, and the anterior intestine (October 2012 and May 2015 only) was screened for intestinal coccidiosis. Photographs were taken with a Jenoptik ProgRes Speed XT core 3 microscope-mounted digital camera.

\section{Fresh liver and intestinal coccidia collection}

In January 2015, 60 freshly captured Atlantic herring were analyzed for the presence of G. clupearum. The fish were first measured by taking total body length $(\mathrm{BL}, \mathrm{cm})$ and body weight $(\mathrm{BW}, \mathrm{g})$, from which the Fulton's $K$ index $\left(K=\mathrm{BW} / \mathrm{BL}^{3} \times 100\right)$ was used to calculate the condition factor of fish. Whole livers were dissected and homogenized, and wet mounts were prepared for analysis by light microscopy. To identify the infection intensity with the coccidian, the total number of oocysts was counted in 4 fields of view under 200x magnification. Linear regression analysis was then used to determine if an association existed between fish condition and intensity of G. clupearum in the liver. Measurements were made directly from digital images of fresh parasites using the Jenoptik imaging software; measurements taken included oocyst diameter and sporocyst length and width. Additionally, the sporocyst length/width relationship was calculated. Samples containing the highest infection intensity were selected for molecular analysis. These were diluted in phosphate-buffered saline (PBS) and filtered through gauze to remove host liver tissue. Samples were then centrifuged, the supernatant was removed, and the pellet was frozen at $-80^{\circ} \mathrm{C}$ for future molecular analysis. For molecular and morphological comparison of G. clupearum from this study to the respective parasite in Pacific herring, liver samples were collected from 30 pre-spawn adult Pacific herring (fork length $228 \pm 26 \mathrm{~mm}$ ), collected from Sitka Sound, Alaska, on March 22, 2015. Tissues were stored on ice and processed within $48 \mathrm{~h}$ for G. clupearum as described for Atlantic herring samples earlier in this paragraph. A 2-tailed $t$-test was used to compare parasite dimensions between the Atlantic and Pacific G. clupearum.

The presence of intestinal coccidians was assessed from 30 Atlantic herring (January 2015 collection). Wet mounts of intestinal mucus were analyzed using a Zeiss Stemi 2000C stereomicroscope; samples containing unsporulated coccidia were transferred to
$15 \mathrm{ml}$ conical tubes containing $5 \mathrm{ml}$ of seawater supplemented with $200 \mathrm{U}$ penicillin $\mathrm{ml}^{-1}, 200 \mu \mathrm{g}$ streptomycin $\mathrm{ml}^{-1}$, and $0.5 \mu \mathrm{g}$ amphotericin $\mathrm{B} \mathrm{ml}^{-1}$ (Lonza). Samples were incubated in the dark at room temperature for $48 \mathrm{~h}$, after which they were examined for sporulation of oocysts using light microscopy. Length and width were measured from fresh preparations of sporulated oocysts and sporocysts using Jenoptik imaging software, and the length/width relationship was calculated.

\section{VHSV virological analysis}

Because of the timing of fish collection, samples for cell culture and real-time reverse transcription polymerase chain reaction (RT-PCR) were collected from previously frozen fish, with the exception of May 2015, when fish were refrigerated overnight and sampled the next day. For dissection of the organ pools from frozen fish, fish and organs were maintained frozen during dissection of brain and head kidney. The organs were aseptically removed, placed into Whirlpak bags, and transported frozen to the New Jersey Department of Agriculture Animal Health Diagnostic Laboratory (Ewing, New Jersey). The tissue pools included 5 fish pools of brain, head kidney, and spleen; in May 2015 and January 2016, gill was also included in the pooled tissue sample (Table 1). Tissue pools were thawed, homogenized, routinely processed for viral isolation on epithelioma papulosum cyprinid (EPC) cells, and observed for cytopathic effect (CPE) at $15^{\circ} \mathrm{C}$ for $14 \mathrm{~d}$. Lacking $\mathrm{CPE}$, a blind passage was performed after $14 \mathrm{~d}$ by re-inoculating newly seeded EPC cells and incubating for an additional $14 \mathrm{~d}$.

Samples were tested using real-time RT-PCR from 2014 to 2016 using 2 different methods. Briefly, in 2014, using methods adapted from Phelps et al. (2012), a small sample of the tissue homogenate (see previous paragraph) was reserved for RNA extraction using a MagMAX Total RNA Isolation Kit (Ambion) with automated sample processing using a KingFisher Flex (Ambion). RT-PCR reactions were run in $20 \mu \mathrm{l}$ reaction volumes consisting of $5 \mu \mathrm{l}$ extracted RNA, $5 \mu$ of $4 \mathrm{X}$ TaqMan ${ }^{\circledR}$ Fast Virus 1-Step Master Mix (Applied Biosystems), $1 \mu$ l each of forward and reverse primers (10 $\mu \mathrm{M}$ each), $1 \mu \mathrm{l}$ probe $(5 \mu \mathrm{M})$, and $7 \mu \mathrm{l}$ RT-PCR grade water. Primers (Invitrogen) and a probe (Applied Biosystems) specific to the N-gene were used: the VHSV N-gene forward (5'-ATG AGG CAG GTG TCG GAG G-3'), VHSV N-gene reverse (5'-TGT AGT AGG ACT CTC CCA GCA TCC-3'), 
and MGB N-gene probe (5'-FAM-TAC GCC ATC ATG ATG AGT-MGBNFQ-3'). RT-PCR was run on an ABI 7500 qPCR thermocycler (Applied Biosystems) under the following conditions: reverse transcription at $50^{\circ} \mathrm{C}$ for $5 \mathrm{~min}$, reverse transcriptase inactivation and initial denaturation at $95^{\circ} \mathrm{C}$ for $20 \mathrm{~s}$, and 40 cycles of amplification at $95^{\circ} \mathrm{C}$ for $3 \mathrm{~s}$ and $60^{\circ} \mathrm{C}$ for $30 \mathrm{~s}$. In 2015 and 2016, testing was conducted by New Jersey Department of Agriculture staff using protocols provided by the US Department of Agriculture National Veterinary Services Laboratories published by Jonstrup et al. (2013) and evaluated by Warg et al. (2014). Future RT-PCR testing for VHSV will utilize the methods adopted in 2015.

\section{G. clupearum molecular analysis}

DNA extraction, polymerase chain reaction, and DNA sequencing

DNA was extracted using a QIAamp DNA Stool Mini Kit (Qiagen) and a QIAcube (Qiagen) according to the manufacturer's instructions. Portions of the small subunit 18S rDNA (ssrDNA) were amplified in $50 \mu \mathrm{l}$ volumes using $3 \mu \mathrm{l}$ of DNA template and a final concentration of $1 \mathrm{X}$ polymerase chain reaction (PCR) buffer, $1.5 \mathrm{mM} \mathrm{MgCl}_{2}, 0.2 \mathrm{mM}$ dNTPs, $0.5 \mu \mathrm{M}$ of each primer (primer details provided in the next paragraph), and 1.25 U Taq polymerase (Invitrogen). PCRs were performed on a Veriti thermocycler (Applied Biosystems) with initial denaturation at $95^{\circ} \mathrm{C}$ for 3 min, followed by 35 amplification cycles at $94^{\circ} \mathrm{C}$ for $30 \mathrm{~s}$, annealing at $50^{\circ} \mathrm{C}$ for $45 \mathrm{~s}$, and extension at $72^{\circ} \mathrm{C}$ for $75 \mathrm{~s}$. A final extension was run at $72^{\circ} \mathrm{C}$ for $7 \mathrm{~min}$. The amplified products were visualized with ultraviolet light on a 1.2\% agarose E-gel (Invitrogen) containing ethidium bromide. Samples containing a single product at approximately $1000 \mathrm{bp}$ size were purified with ExoSAP-IT (Affymetrix) and diluted to $3 \mathrm{ng}$ of DNA $\mathrm{\mu l}^{-1}$ with molecular-grade water. Sequencing was performed in both directions using a $5 \mu \mathrm{M}$ final concentration of the amplification primers. DNA sequencing was completed by GENEWIZ using ABI BigDye version 3.1 and run on an ABI 3730xl DNA analyzer (Applied Biosystems).

Initially, 2 sets of primers specific for coccidia were used for each sample: the 18E (5'-CTG GTT GAT CCT GCC AGT) forward and Coc2r (5'-CTT TCG CAG TAG TTC GTC) reverse primers (Whipps et al. 2012) and the Coc1f (5'-GAT TAA TAG GGA CAG TTG) forward and 18R (5'-CTA CGG AAA CCT TGT TAC G) reverse primers (C. M. Whipps pers. comm.).
The Coc1f/18R primers amplified and yielded a single product around $1000 \mathrm{bp}$, which was selected for sequencing. However, the 18E/Coc2r primers were unsuccessful in amplifying the target region. A new reverse primer, Gclup2r (5'-AGG AGA AGT CGG AGA GAC G), was designed based on the sequence results of the Coc1f/18r region and used with the $18 \mathrm{E}$ forward primer. The annealing temperature was modified from 50 to $54^{\circ} \mathrm{C}$, but all other cycling conditions remained the same. This primer set amplified and yielded a single product containing approximately $1000 \mathrm{bp}$. PCR, product visualization, purification, and sequencing were then performed as described in the previous paragraph.

Sequence alignment and phylogenetic analysis

DNA sequence chromatograms were visually inspected and edited using Chromas Lite version 2.1 and aligned using the BioEdit version 7.2.5 sequence alignment editor (Hall 1999). After alignment with ClustalW, a consensus sequence was generated and checked against all known sequences from the GenBank DNA database using the Basic Local Alignment Search Tool (BLAST) from the National Center for Biotechnology Information (NCBI). Sequences were confirmed to be most closely related to other known coccidian species. Phylogenetic analyses were performed using MEGA7 (Kumar et al. 2016). The evolutionary history was inferred by using the maximum likelihood method based on the general timereversible model (Nei \& Kumar 2000). The tree with the highest log likelihood (-5569.0826) is shown. The percentage of trees in which the associated taxa clustered together is shown next to the branches. Initial tree(s) for the heuristic search were obtained automatically by applying neighbor-join and BioNJ algorithms to a matrix of pairwise distances estimated using the maximum composite likelihood approach and then selecting the topology with superior log likelihood value. A discrete gamma distribution was used to model evolutionary rate differences among sites ( 5 categories $[+G$, parameter $=0.2330]$ ). The rate variation model allowed for some sites to be evolutionarily invariable $([+\mathrm{I}], 37.2419 \%$ sites $)$. The tree is drawn to scale, with branch lengths measured in the number of substitutions per site. The analysis involved 21 nucleotide sequences. All positions with less than $95 \%$ site coverage were eliminated. That is, fewer than $5 \%$ alignment gaps, missing data, and ambiguous bases were allowed at any position. There were 1356 positions in the final dataset. 


\section{Direct infectivity of $G$. clupearum to Pacific herring}

A controlled experiment was performed to investigate the direct infectivity of $G$. clupearum oocysts to Pacific herring. Experimental inocula consisted of $G$. clupearum oocysts obtained from the livers of wild Pacific herring. Livers were screened by microscope squash preparations from 30 wild-captured Pacific herring, which were euthanized with an overdose of MS-222. Heavily infected livers were pooled and homogenized in Whirl-pak bags, followed by dilution with PBS. The diluted liver homogenate was filtered through cheesecloth packed into a syringe to remove large tissue debris. The sample was allowed to settle overnight at $4^{\circ} \mathrm{C}$, and the supernatant was replaced with fresh PBS. The oocyst preparation was used within $72 \mathrm{~h}$. Prior to infection of fish, oocyst counts were made by re-suspending in PBS and using a hemocytometer to estimate the number of sporocysts. The final preparation was diluted to contain at least 5000 sporocysts $\mathrm{ml}^{-1}$. Experimental animals, consisting of age $0 \mathrm{yr}$ specific pathogen-free Pacific herring (Hershberger et al. 2007), were maintained in $260 \mathrm{l}$ circular tanks supplied with single-pass, filtered, and UV-irradiated seawater. The experimental fish were each exposed to about $500 \mathrm{G}$. clupearum sporocysts within a $100 \mu$ l suspension by gastric gavage $(\mathrm{n}=27)$; negative controls $(n=60)$ were exposed to PBS in lieu of parasite suspensions. Gastric gavage was done by syringe with soft flexible tubing attached; fish were lightly anesthetized with MS-222, intubated with $100 \mu \mathrm{l}$ of suspension into the stomach, and transferred to the research tank to recover. Following exposures, fish were maintained on a diet of commercial pellets (Bio-Olympic). Fish were fed to satiation every 2 to
$3 \mathrm{~d}$. Mortalities were sampled daily, and survivors were subsampled at 21,43 , and $77 \mathrm{~d}$ post-exposure (n $=4 \mathrm{~d}^{-1}$ ). Liver squash preparations from all sampled herring were examined microscopically $(200 \times$ magnification) for the presence of $G$. clupearum oocysts.

\section{RESULTS}

\section{VHSV and Ichthyophonus hoferi surveillance in Atlantic herring}

Throughout the course of this study (April 2013 to January 2016), VHSV was not detected by either cell culture $(\mathrm{n}=524)$ or RT-PCR $(\mathrm{n}=304)$. Likewise, I. hoferi was not detected in hearts by histology $(\mathrm{n}=160)$.

\section{Goussia clupearum in Atlantic herring}

G. clupearum occurred in $78 \%$ (47 of 60 ) of fresh preparations from liver tissue sampled in January 2015. The intensity of infection ranged from light to severe, with the heaviest being over 800 oocysts observed in 4 fields of view at 200x magnification. Severe infection, defined as having over 300 oocysts in 4 microscope fields under $200 \times$ magnification, occurred in $10 \%$ of the sampled fish. No association was seen between infection intensity and fish condition factor $K$. The sporulated oocysts were spherical, with a smooth, thin wall and variation in size (range $=20.1-31.3 \mu \mathrm{m})($ Fig. 1A). Oocysts contained 4 ellipsoidal sporocysts which each contained 2 sporozoites and abundant sporocyst residuum. Measurements for sporulated oocysts and sporocysts are summarized in Table 2.

Table 2. Measurements of oocyst and sporocyst diameter, length, width, and length/width (L/W) relationship \pm standard deviation (SD) in Goussia clupearum from Atlantic and Pacific herring and G. echinata from Atlantic herring with spine length. na: not applicable

\begin{tabular}{|c|c|c|c|c|c|c|c|}
\hline Goussia spp. & $\begin{array}{l}\text { Oocyst diameter } \\
\text { or length }(\mu \mathrm{m}) \\
\pm \mathrm{SD} \text { (range) }\end{array}$ & $\begin{array}{l}\text { Oocyst width } \\
(\mu \mathrm{m}) \pm \mathrm{SD} \\
(\text { range })\end{array}$ & $\begin{array}{l}\text { Oocyst L/W } \\
(\mu \mathrm{m}) \pm \mathrm{SD} \\
\text { (range) }\end{array}$ & $\begin{array}{c}\text { Sporocyst } \\
\text { length }(\mu \mathrm{m}) \\
\pm \mathrm{SD} \text { (range) }\end{array}$ & $\begin{array}{c}\text { Sporocyst } \\
\text { width ( } \mu \mathrm{m}) \\
\pm \mathrm{SD} \text { (range) }\end{array}$ & $\begin{array}{c}\text { Sporocyst } \\
\text { L/W ( } \mu \mathrm{m}) \\
\pm \mathrm{SD} \text { (range) }\end{array}$ & $\begin{array}{l}\text { Spine length } \\
(\mu \mathrm{m}) \pm \mathrm{SD} \\
\text { (range) }\end{array}$ \\
\hline G. clupearum & $25.4 \pm 2.4$ & na & na & $11.7 \pm 0.9$ & $8.4 \pm 0.8$ & $1.4 \pm 0.1$ & na \\
\hline (Atlantic) & $\begin{array}{c}(20.1-31.3) \\
\text { (diameter), } \mathrm{n}=85\end{array}$ & & & $\begin{array}{l}(9.6-14.2) \\
\mathrm{n}=100\end{array}$ & $\begin{array}{l}(6.9-10.8) \\
\mathrm{n}=100\end{array}$ & $\begin{array}{c}(1.0-1.7) \\
\mathrm{n}=100\end{array}$ & \\
\hline G. clupearum & $21.1 \pm 1.1$ & na & na & $10.7 \pm 0.8$ & $7.6 \pm 0.4$ & $1.4 \pm 0.1$ & na \\
\hline (Pacific) & $\begin{array}{c}(18.4-25.4) \\
\text { (diameter), } \mathrm{n}=85\end{array}$ & & & $\begin{array}{l}(8.7-12.9) \\
\mathrm{n}=100\end{array}$ & $\begin{array}{l}(6.4-8.6) \\
(\mathrm{n}=100)\end{array}$ & $\begin{array}{c}(1.1-1.7) \\
\mathrm{n}=100\end{array}$ & \\
\hline $\begin{array}{l}\text { G. echinata } \\
\text { n. sp. }\end{array}$ & $\begin{array}{c}18.7 \pm 0.5 \\
(18.0-19.3) \\
\text { (length), } \mathrm{n}=6\end{array}$ & $\begin{array}{c}11.1 \pm 0.9 \\
(9.4-11.7) \\
n=6\end{array}$ & $\begin{array}{c}1.7 \pm 0.2 \\
(1.5-2.0) \\
n=6\end{array}$ & $\begin{array}{c}9.2 \pm 0.9 \\
(7.8-11.1) \\
\mathrm{n}=13\end{array}$ & $\begin{array}{c}4.1 \pm 0.5 \\
(2.9-4.8) \\
\mathrm{n}=13\end{array}$ & $\begin{array}{c}2.3 \pm 0.5 \\
(1.9-3.8) \\
\mathrm{n}=13\end{array}$ & $\begin{array}{c}15.1 \pm 5.1 \\
(2.9-20.8) \\
\mathrm{n}=19\end{array}$ \\
\hline
\end{tabular}



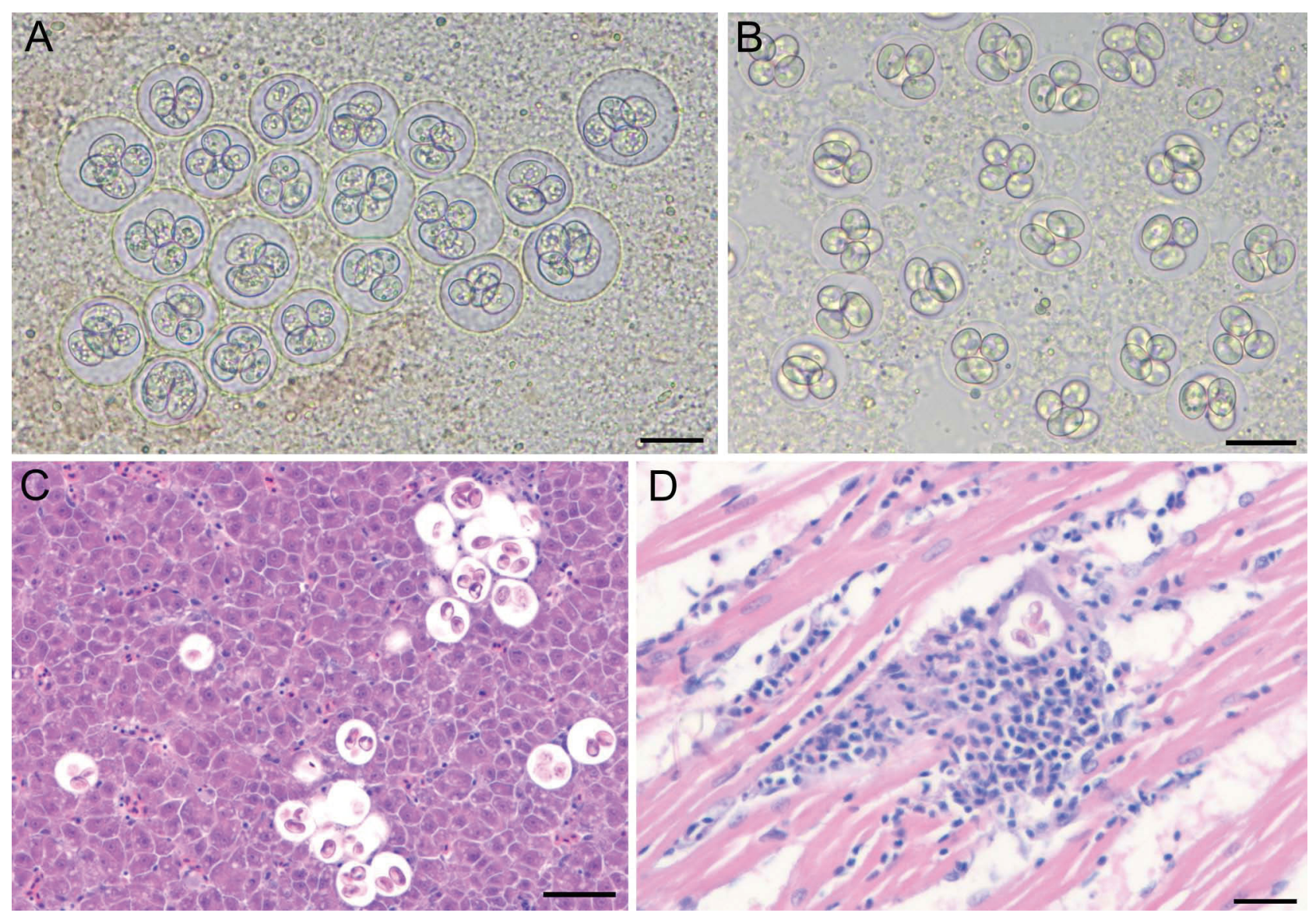

Fig. 1. Goussia clupearum. Scale bars $=20 \mu \mathrm{m}$. Wet mounts of fresh homogenized liver tissue with (A) oocysts in Atlantic herring showing size variation of oocysts and (B) oocysts in Pacific herring. $\left(C_{,} D\right)$ Histology of Atlantic herring stained with hematoxylin and eosin (H\&E) showing (C) aggregates of oocysts in liver tissue and (D) Atlantic herring heart infected with coccidia resembling G. clupearum showing inflammatory response

Histological assessment of liver sections indicated prevalences of $40 \%$ (April 2013), $75 \%$ (January 2015), and 55\% (May 2015). Oocysts frequently occurred in aggregates (Fig. 1C), often surrounded by a yellow-brown cellular matrix, resembling pigmented macrophage aggregates. No notable lesions were observed in the hepatocytes, and no significant inflammatory response was observed, even in cases of heavy infection. In 2 fish, hearts that were screened for I. hoferi using histology had light infection with a coccidian consistent with G. clupearum. These oocysts were surrounded by multiple layers of inflammatory cells (Fig. 1D).

\section{G. clupearum measurements from Atlantic and Pacific herring}

The G. clupearum oocysts observed in fresh wet mounts of Atlantic and Pacific herring liver homo- genates were similar in shape and morphology (Table 2, Fig. 1A,B). However, the mean oocyst diameter was significantly different in the Atlantic and Pacific herring $(p<0.001)$, with the range of dimensions indicating that the oocysts from Pacific herring were slightly smaller. The sporocyst morphology appeared similar between clupeid hosts; however, the length and width of sporocysts from Pacific herring were again slightly smaller $(p<0.001)$ (Table 2$)$. The sporocyst length/width ratio was not significantly different between the host species.

\section{Sequencing and phylogenetic analysis of G. clupearum from Atlantic and Pacific herring}

Analysis of the small subunit 18S rRNA gene in $G$. clupearum from Atlantic herring yielded a $1757 \mathrm{bp}$ consensus DNA sequence, deposited in GenBank under accession number KT025255. For Pacific herring, a 
Table 3. Nucleotide differences observed between small subunit 18S rDNA sequences of Goussia clupearum from Atlantic and Pacific herring based on alignment to Atlantic sequence and number of nucleotides

\begin{tabular}{|lcc|}
\hline Position & Atlantic & Pacific \\
\hline 180 & $\mathrm{C}$ & $\mathrm{T}$ \\
249 & $\mathrm{~A}$ & $\mathrm{G}$ \\
649 & $\mathrm{~T}$ & $\mathrm{~A}$ \\
656 & $\mathrm{G}$ & $\mathrm{A}$ \\
719 & $\mathrm{~T}$ & - \\
1350 & $\mathrm{~T}$ & - \\
\hline
\end{tabular}

1749 bp consensus DNA sequence was generated and deposited under accession number KT025256. Comparison of the 2 sequences, based on alignment of 1749 nucleotides, demonstrated significant identity $(99.6 \%)$. Differences in the 2 sequences included 4 nucleotide substitutions and 2 gaps (Table 3 ).
When the G. clupearum sequences were compared to other coccidia using BLAST (NCBI), the closest identities were with coccidia in the Calyptospora genus, including C. funduli, C. spinosa, and C. serrasalmi. The closest match was with $C$. funduli (accession number GU479670.1), which had 92\% query cover and $94 \%$ identity. When aligned to all coccidia, the query coverage never exceeded $92 \%$ because $G$. clupearum had an approximately 124-nucleotide insertion that did not occur in any other coccidian species. This insertion occurred from nucleotide positions 605 to 729 , based on the 1757 nucleotide sequence from Atlantic herring G. clupearum (KT025255). A search for similarities to this 124-nucleotide sequence did not reveal any significant similarities using BLAST. Three of the nucleotide differences between the Pacific and Atlantic G. clupearum occurred within this unique 124-nucleotide region. Phyloge-

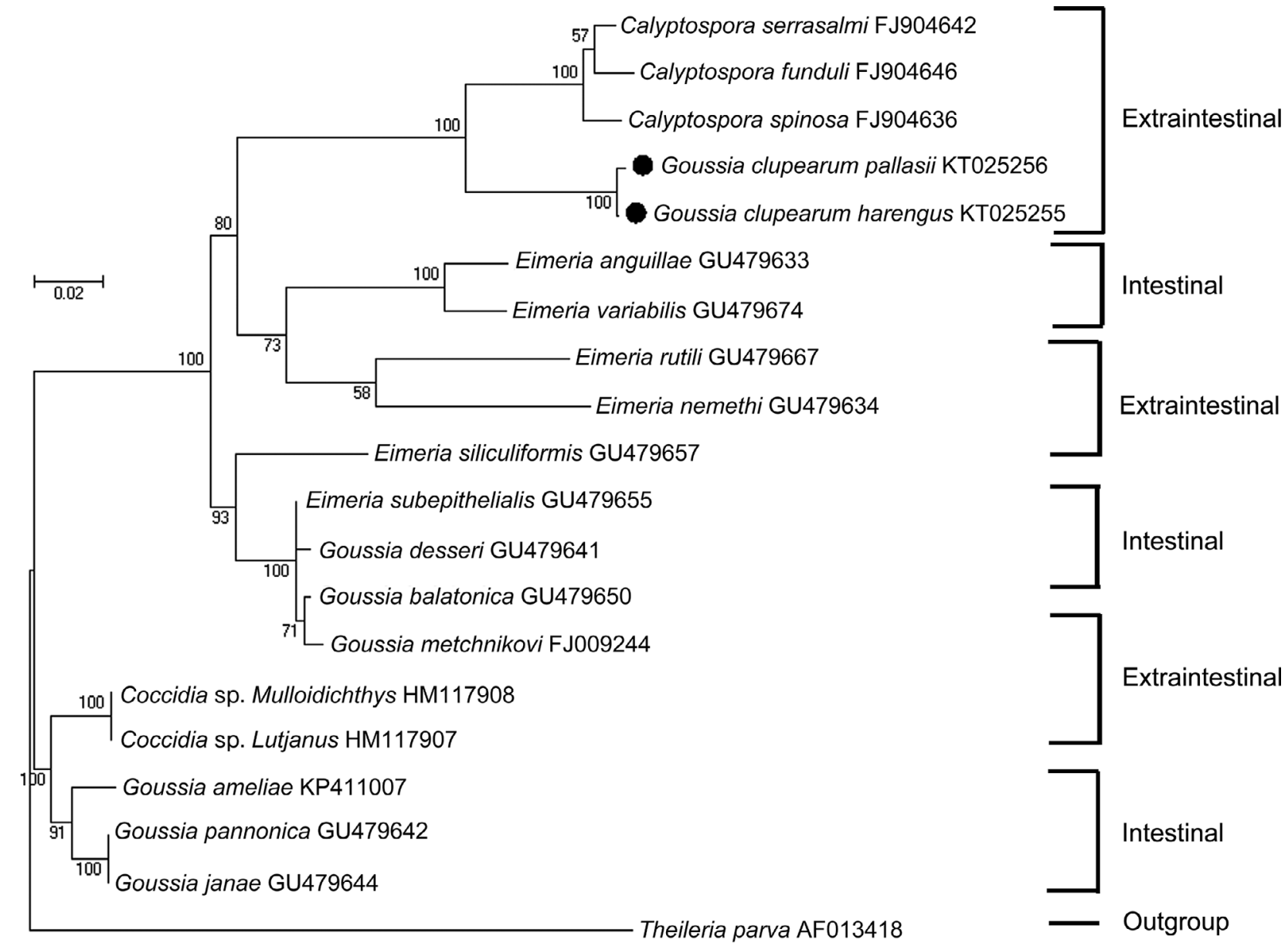

Fig. 2. Phylogenetic tree constructed using the criterion of maximum likelihood analysis based on variation in the small subunit rRNA gene from 21 sequences obtained from GenBank and 2 sequences from this study (Goussia clupearum, denoted by $)$. G. clupearum groups most closely with other extraintestinal liver coccidia of fish and is distinct from intestinal fish coccidia. Theileria parva was used as an outgroup to root the tree. Branch lengths shown here are proportional to the number of substitutions (as shown by the scale bar). Bootstrap support is represented by the numbers at the internal nodes 
netic analysis demonstrated that $G$. clupearum grouped most closely to other extraintestinal coccidians within the Calyptospora genus (Fig. 2).

\section{Direct infectivity of $G$. clupearum to Pacific herring}

G. clupearum was not detected in the livers of any Pacific herring that were exposed to parasite suspensions by gastric gavage, including 4 mortalities $(3,9$, 19 , and $34 \mathrm{~d}$ post-exposure) and 12 subsampled survivors (4 each at 21,43, and 76 d post-exposure). Similarly, G. clupearum was not detected in any negative controls (mortalities or subsampled survivors).

\section{Intestinal coccidiosis in Atlantic herring}

In October 2012, 10 juvenile Atlantic herring were collected and screened by histology for signs of parasites and diseases. In 6 of the fish, a coccidian parasite was observed attached to the intestinal epithelial cells within the pyloric ceca (Fig. 3), with microgametocytes and macrogamonts found in an epicellular position within the epithelium (Fig. 3).

Because intestinal coccidiosis had not been previously described in Atlantic herring, additional anterior intestine and pyloric cecum samples were subsequently examined from 30 adult herring, collected in
January 2015. Because of the timing and location of collection, fresh wet mounts could not be prepared until nearly $24 \mathrm{~h}$ after fish were collected. At the time of wet mount preparation, the digestive tract had some post-mortem changes related to autolysis. Unsporulated oocysts were identified in one sample of intestinal mucus. After incubation for $48 \mathrm{~h}$, the oval unsporulated oocysts had fully sporulated. Oocysts were oval, with a smooth, thin wall and no oocyst residuum, micropyle, or polar granules visible under light microscopy (Fig. 4). Within the oocyst were 4 ellipsoidal sporocysts, each containing 2 sporozoites and plentiful sporocyst residuum. Stieda bodies were not observed under light microscopy. The most notable and unexpected feature of these oocysts was the presence of 6 variably long spines projecting from the wall of the oocyst, with 3 spines on each pole of the oocyst (Figs. 4 $\& 5)$. The spines contained a narrow lumen, which appeared to be continuous with the oocyst wall. The length of the spines varied from 2.9 to $20.8 \mu \mathrm{m}$, with an average length of $15.1 \mu \mathrm{m}$ (Table 2). The novel morphology of this coccidian led us to tentatively name this parasite $G$. echinata n. sp., as described in the next subsection. The sample was saved for molecular analysis. However, attempts to amplify the DNA using the previously reported coccidian primers were unsuccessful. This may be related to the relatively small numbers of oocysts in the sample preparation, or it is also possible that the currently used coccidian primers were not compatible with this species.
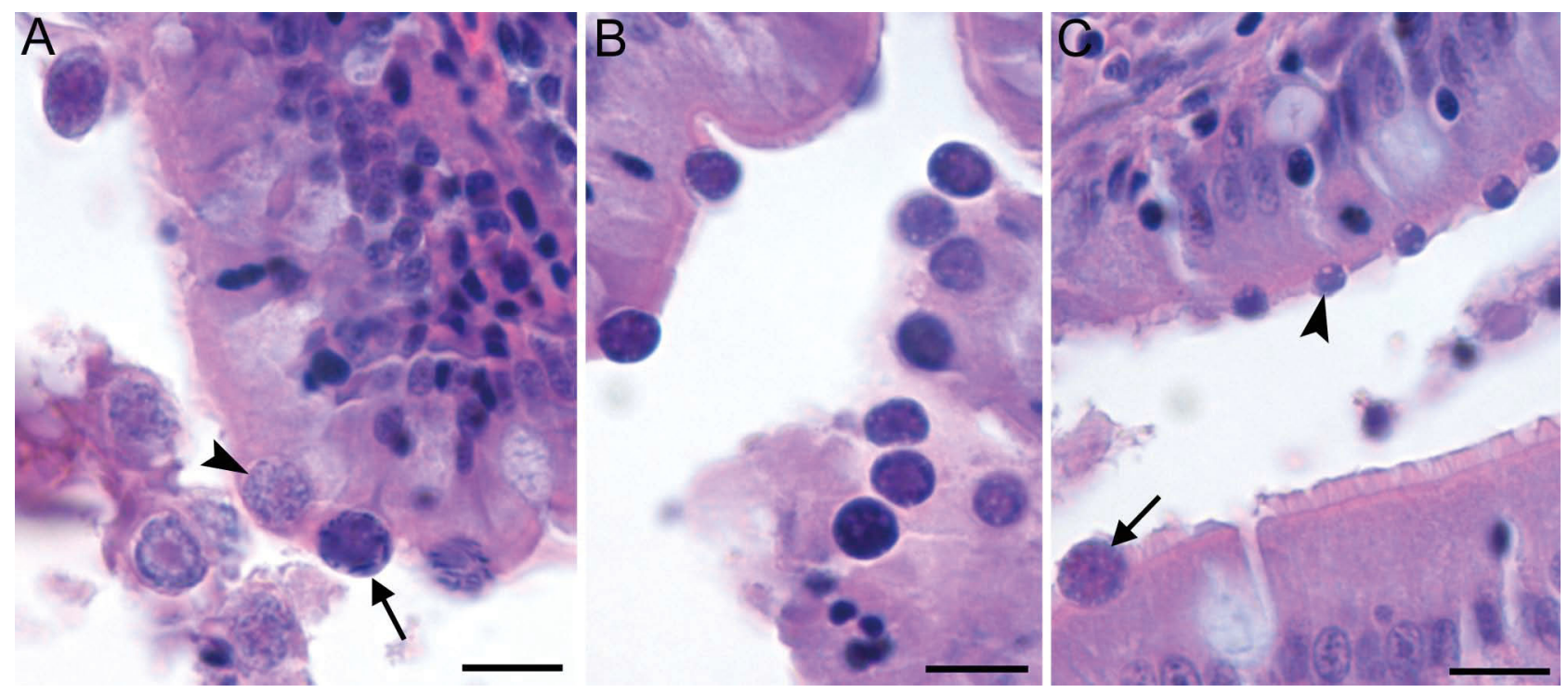

Fig. 3. Histology of various stages of coccidian infection in juvenile Atlantic herring within the pyloric ceca, stained with hematoxylin and eosin $(\mathrm{H} \& \mathrm{E})$; scale bars $=10 \mu \mathrm{m}$. (A) Epicellular position of microgametocyte (arrow) and macrogamont (arrowhead), (B) macrogamonts embedded in the epithelium, and (C) early developmental stages (arrowhead) and macrogamont (arrow) within the brush border of the epithelium 

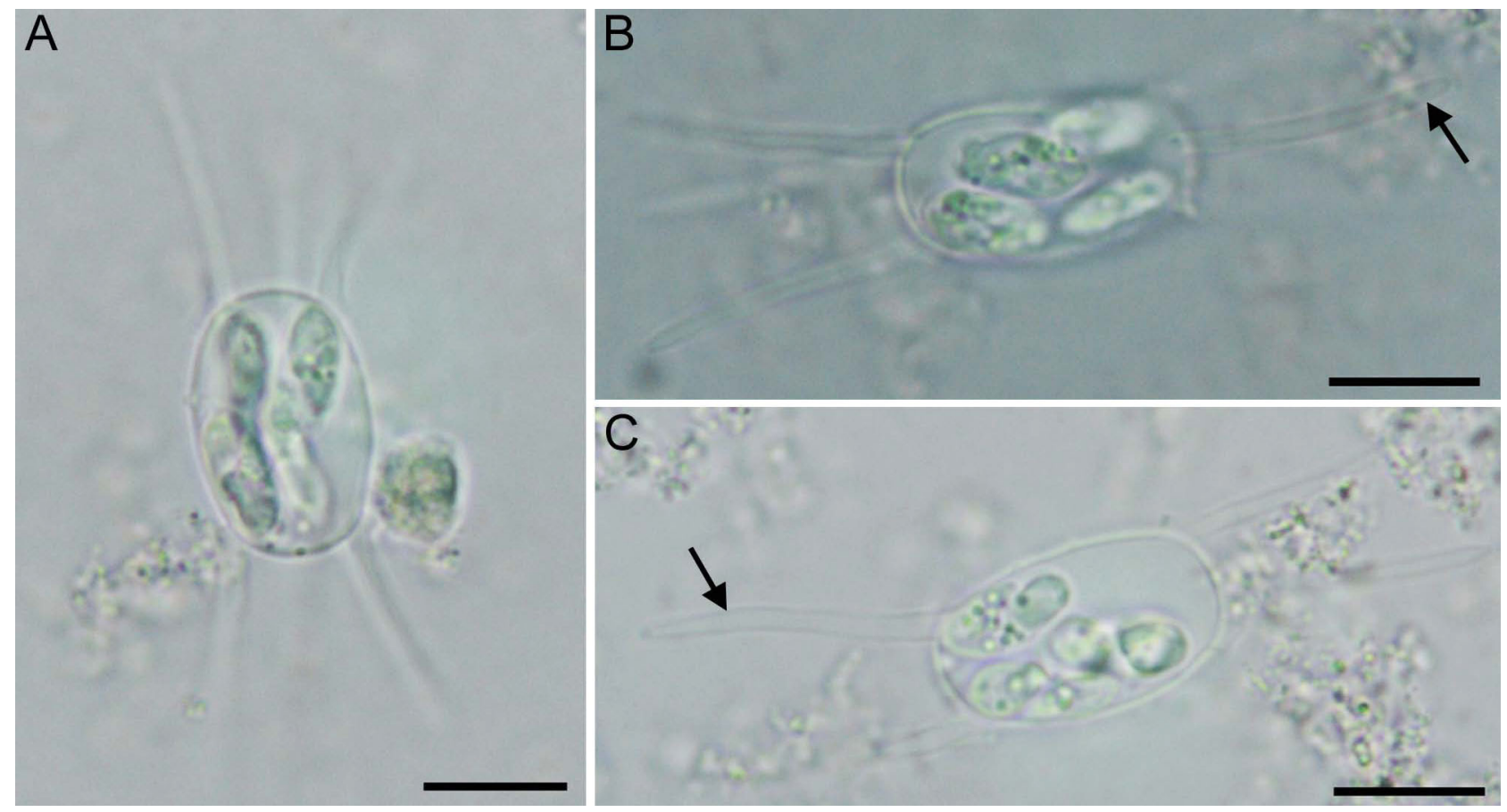

Fig. 4. Goussia echinatan. sp. from the intestine of Atlantic herring. Scale bars $=10 \mu \mathrm{m}$. (A-C) Wet mounts of sporulated oocysts showing smooth oocyst wall with long, spiny projection (arrows). Oocysts contain 4 ellipsoidal sporocysts

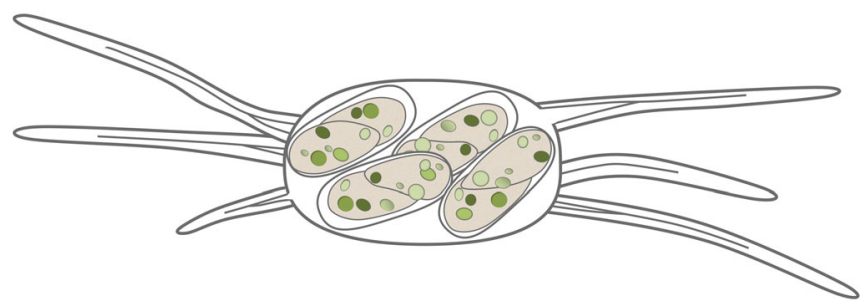

Fig. 5. Diagram of sporulated oocyst of Goussia echinata n. sp. in Atlantic herring. Scale bar $=5 \mu \mathrm{m}$

In May 2015, 20 adult Atlantic herring were collected and preserved in $10 \%$ NBF for additional histological observations of the anterior intestine and pyloric ceca. During this time, only 4 fish could be collected for fresh examination of intestinal mucus. Of the 20 fish collected for histology, 11 contained coccidia in the pyloric ceca (55\% prevalence). The coccidian infection was very light, with no associated lesions in the intestinal epithelium (Fig. 6A-E). Because of the light infection intensity in these fish and limited availability of fresh fish $(\mathrm{n}=4)$, fresh preparations of the parasite were unsuccessful. In histology, only epicellular coccidia were observed in the anterior intestine of all adult herring sampled. It is possible that 2 different species of epicellular coccidians exist in the tissue. The macrogamonts in the adult herring gut histology were significantly elon- gated (Fig. 6C-E), which corresponds more with the elongated sporulated oocysts seen in fresh preparations from adult fish sampled in January 2015 (Fig. 4), whereas those observed in the juvenile herring gut histology from 2012 were mainly spherical (Fig. 3). Considering the likelihood that 2 species of coccidians are infecting the intestine of herring, the histology and wet mount preparations of the coccidian could not be definitively linked.

\section{Taxonomic description}

Goussia echinata n. sp. (Figs. 4A-C \& 5)

Type host: Atlantic herring Clupea harengus

Other host: Unknown

Type locality: NW Atlantic Ocean, New Jersey, USA $\left(40^{\circ} \mathrm{N}, 74^{\circ} \mathrm{W}\right)$

Other localities: Unknown

Site of infection: Anterior intestine, pyloric cecum Prevalence: Unknown

Intensity: Unknown

Phototypes: Catalogued at the NJDFW Fish Pathology Laboratory, Oxford, New Jersey 07863, USA

Parasite description: Epicellular coccidian with exogenous sporulation. Unsporulated oocysts from fresh preparations were ovoid, with a smooth wall and no projections or spines. Sporulation occurred exoge- 

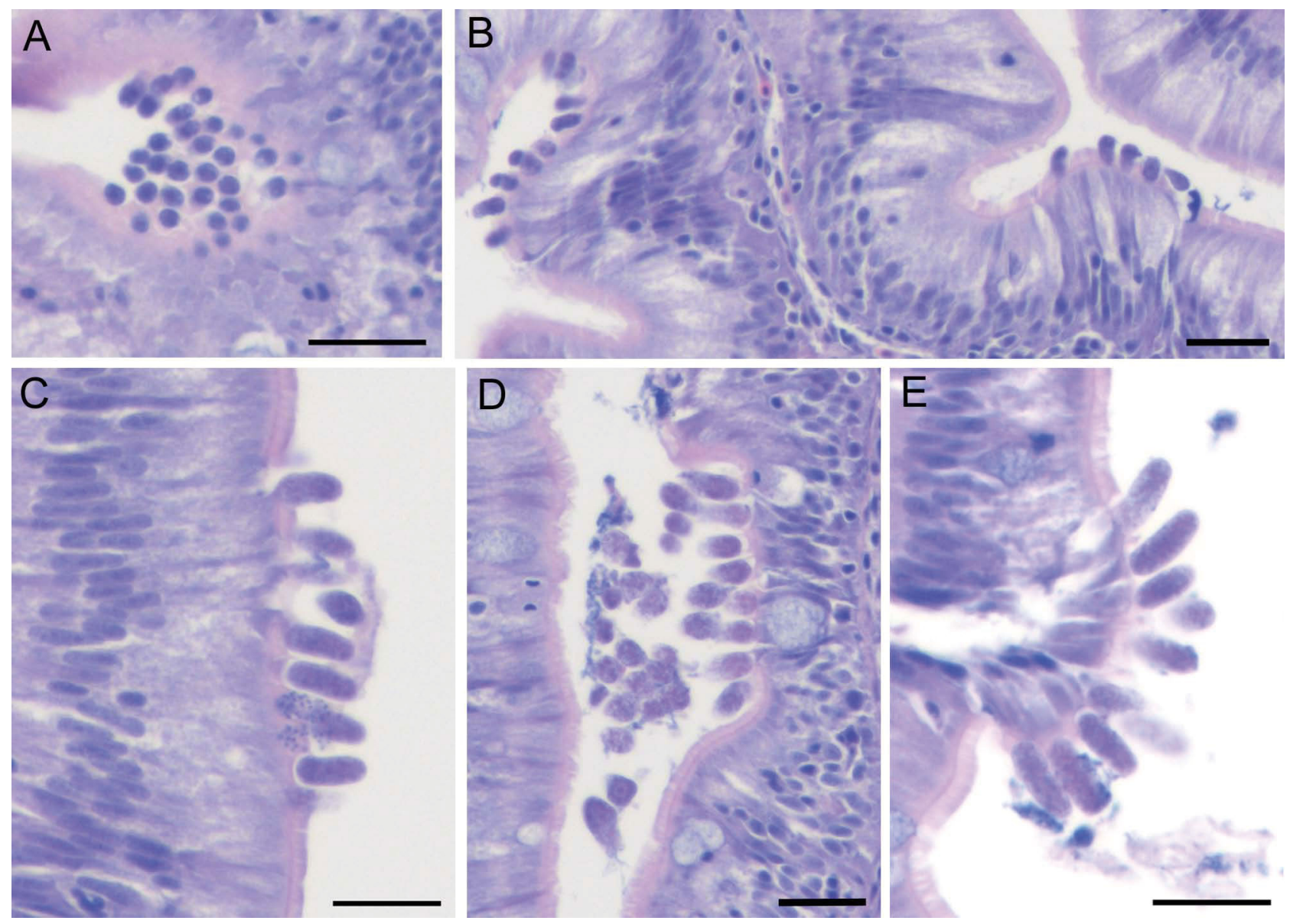

Fig. 6. Histology of coccidian infection in adult Atlantic herring within the pyloric ceca, stained with hematoxylin and eosin (H \& E); scale bars $=20 \mu \mathrm{m}$. (A-E) Various stages of coccidia infection showing (C-E) elongated macrogamonts and (D) indentation of the epithelium, with little disruption of the brush border

nously within $48 \mathrm{~h}$; oocysts were ovoid, with a smooth, thin wall. Each end (pole) of the oocyst bears 3 spinelike projections with an average length of $15.1 \mu \mathrm{m}$; however, the length was highly variable (2.9$20.8 \mu \mathrm{m})$. A lumen occurred within the spine-like projections. Oocysts (excluding spine length) measured $18.7 \times 11.1 \mu \mathrm{m}(18.0-19.3 \times 9.4-11.7) \quad(\mathrm{n}=6) ;$ length/width relationship $1.7(1.5-2.0)(n=6)$. Oocyst residuum, micropyle, or polar granules absent. Four ellipsoidal sporocysts, measuring $9.2 \times 4.1(7.8-11.1 \times$ 2.9-4.8) $(\mathrm{n}=13)$, each contained 2 sporozoites and plentiful sporocyst residuum. A Stieda body was not observed under light microscopy. A line drawing of the sporulated oocyst is shown in Fig. 5; measurements are summarized in Table 2.

Pathology: Epicellular infection of gastrointestinal epithelial cells, with no apparent lesions.

Etymology: Name is derived from the Latin word echinatus, meaning spiny or prickly, and refers to the unique spiny projections that occur in this species.

\section{DISCUSSION}

This is the first study to provide genetic information on Goussia clupearum in Atlantic and Pacific herring to clarify their taxonomic position and to understand the relatedness of the 2 similar parasite species. The small differences in the nucleotide sequence reported here between G. clupearum in Atlantic and Pacific herring indicate some divergence between the parasites in the 2 geographically separated host species, though they are mostly conserved with $99.6 \%$ identity. Less-conserved genes, such as the internal transcribed spacer (ITS) gene (White et al. 1990, Barta et al. 1998), would likely aid in determining additional details in the divergence within these species. Though the small changes in the ssrDNA of $G$. clupearum are notable between the 2 host herring species, additional sampling from different populations within these hosts is necessary to establish whether the level of variation observed here is at the 
host species level or also observed across wider geographical areas within a host species range.

Further work on liver Goussia sp. from outside the clupeid genus would aid in determining variations within these liver coccidians in marine fish. From this study, the similar tissue tropisms, parasite morphology, relatively conserved ssrDNA, and common hosts within the genus Clupea support these organisms as the same species. An unexpected finding from this study was the unique 124-nucleotide sequence insertion in positions 605 to 729 , found only in this coccidian species. Despite the unknown relevance of the 124-nucleotide insertion, which does not align with any coccidian species, the remaining portion of the sequence aligns with and shows greatest identity with other extraintestinal liver coccidia from the genus Calyptospora. This is consistent with the findings of Molnár et al. (2012), who have previously shown that the coccidia infecting intestinal sites evolved separately from those occupying extraintestinal tissues. Our analysis places G. clupearum more distantly from other Goussia species, which mainly represent intestinal and epicellular species. Rosenthal et al. (2016) present evidence that parasites presently assigned to the genus Goussia comprise at least 3 distinct evolutionary lineages and represent significant phylogenetic diversity. They further suggest that revision of the taxonomic nomenclature for the myriad species currently ascribed to Goussia may be warranted. Our phylogenetic analysis has a small sample size (21 nucleotide sequences) for elucidating evolutionary relationships but does demonstrate that the extraintestinal Calyptospora genus and G. clupearum grouped separately from other intestinal species, though other extraintestinal species were interspersed within intestinal species. The findings of this study suggest that currently classified G. clupearum is most closely related to extraintestinal species in the Calyptospora genus rather than the predominantly intestinal and epicellular species most frequently placed within the genus Goussia. More work on the evolutionary diversity of fish coccidia is needed to elucidate the relationships between different groups.

Life cycle characteristics may also provide clues to taxonomic structure. It has previously been proposed that the genus Calyptospora can be distinguished from other coccidians by their heteroxenous life cycle (Overstreet et al. 1984). A heteroxenous life cycle has been demonstrated in C. funduli, which requires a developmental period in the gut basal cells of the grass shrimp Palaemonetes pugio prior to transmission to the definitive host, the Gulf killifish Fundulus grandis (Fournie \& Overstreet 1983, Fournie et al. 2000, Whipps et al. 2012). Our results on the infectivity of G. clupearum suggest that transmission is not direct and that passage through an intermediate host is likely. This life cycle characteristic is also supported given the close phylogenetic placement of G. clupearum to the Calyptospora. However, it is also possible that sporocysts introduced through gastric gavage in this study were either no longer viable or that the challenge period was not sufficiently long enough (77 d) to detect the coccidian oocysts in the liver. Further studies on transmission are needed to elucidate the life cycle characteristics of G. clupearum.

Although many coccidia display strong host specificity (Molnár et al. 2005), G. clupearum is reported to parasitize a range of clupeid, scombroid, and gadoid hosts (Costa \& MacKenzie 1994, Abollo et al. 2001). Within those hosts, differences in morphology have been found, particularly in oocyst diameter and sporocyst length and width (MacKenzie 1979, Lom \& Dyková 1992, Abollo et al. 2001, Azevedo 2001). The oocyst and sporocyst dimensions described in this study correlate to ranges summarized by Abollo et al. (2001), with the large range in oocyst diameter we observed in Atlantic herring most similar to a Goussia sp. reported from the liver of blue whiting Micromesistius poutassou (MacKenzie 1979). Several studies of G. clupearum and similar liver coccidia have struggled with confidently assigning a species name based on morphological criteria alone (Costa \& MacKenzie 1994, Abollo et al. 2001). Morphometric data from sporulated oocysts and sporocysts are commonly used to identify morphologically similar coccidian species. However, in the absence of molecular information, it is difficult to determine by morphology alone whether coccidia reported from different hosts truly represent different species or may be conspecific. Molnár et al. (2005) devised cross-infection experiments, which demonstrated strict host specificity for the gut coccidia G. carpelli in common carp Cyprinus carpio. It has been suggested that intestinal coccidia display a higher degree of host specificity than liver coccidia in fish (Abollo et al. 2001). We hope that the availability of reliable primers for the ssrDNA for G. clupearum and the present ease and affordability of sequencing technology might lead other researchers to apply molecular comparisons to any questionable isolates.

G. clupearum is reported as a parasite specific to the liver parenchyma of fish, though other Goussia species have been reported to be less tissue specific (Lom \& Dyková 1992). In the current study, little pathology in terms of cell damage, lesions, and in- 
flammation was associated with infection in the liver. Studies have found that hepatic coccidiosis is a major factor contributing to poor condition in some hosts (MacKenzie 1981, Abollo et al. 2001, Gestal \& Azevedo 2005). We did not observe this effect in the current study. However, with regard to hepatic coccidiosis caused by $G$. clupearum, some differences in effect of body condition seem to be related to the host in question. Costa \& MacKenzie (1994) suggest that $G$. clupearum is not a serious pathogen in herring but is so in other species such as blue whiting. It has been hypothesized that intense infections are likely to stress hosts (Morrison \& Hawkins 1984). Abollo et al. (2001) suggest that the liver is the preferred target organ but that infections may spread to other organs in cases of chronic infection. In the current study, we observed sporulated oocysts consistent with G. Clupearum in low numbers in the hearts of 2 Atlantic herring. Interestingly, these oocysts induced an inflammatory response, which was not seen in the liver of infected fish. Though we cannot rule out the possibility of this being a different coccidian species, it is possible that the presence of $G$. clupearum in this non-target organ elicits an inflammatory reaction, whereas immune responses may be better modulated by the parasite in the liver.

This study documented intestinal coccidiosis in Atlantic herring for the first time. Juvenile Atlantic herring (October 2012) had heavier infection intensities observed in histological sections than did adult fish (May 2015), though infection prevalence was similar, 60 and $55 \%$ in juveniles and adults, respectively. Similar observations have been noted with Pacific herring populations, with young-of-the-year fish having heavier infections and prevalence compared to adult fish (J. Lovy pers. obs.). Given the differences in season of observation, geographic location, age of fish, and macrogamont morphology, it is possible that these are 2 different intestinal coccidia. However, the oblong macrogamonts observed in May 2015 likely correspond to the elongated sporulated oocysts of $G$. echinata n. sp. observed in January 2015 from the same geographic location and population. A fascinating finding in the present study was the unique morphology of $G$. echinata n. sp. sporulated oocysts. The presence of 6 long, spinelike projections from the oocyst wall is unlike any other coccidia reported from fish and rare in any reported coccidian. Several coccidia of turtles have similar but much smaller conical projections. Eimeria stylosa in red-eared sliders Trachemys scripta elegans possesses 2 projections on one end and 3 on the opposite side of its ovoid oocyst wall; however, some variation was observed in the number of projections present. These projections were $4.0 \mu \mathrm{m}$ on average (McAllister \& Upton 1989). E. jirkamoraveci, also from turtles, has 3 blunt, knob-like projections at one end, approximately 1 to $1.5 \mu \mathrm{m}$ long (Široký et al. 2006). E. mitraria, with similar, smaller ornate projections, is found in multiple species of turtles from geographically distant regions and has been suggested to represent a morphotype rather than a species (Široký \& Modrý 2006). G. echinata n. sp., described in the current study, had significantly longer spiny projections than the short, knob-like or conical projections reported from the coccidia of turtles (described in this section). The purpose of the unique long projections found in the coccidial oocyst of this species is currently unknown, though they are likely adaptive traits benefitting the parasite in successfully infecting their hosts. Myxosporean actinospore appendages are hypothesized to help increase buoyancy for better dispersal and may serve to extend suspension time in the water column, facilitating transmission to a host (Kallert et al. 2015). It is possible that the long, spine-like appendages of G. echinata n. sp. serve a similar function, though further work on the life cycle of this parasite will be important in fully understanding the function of this unique adaptation. Unfortunately, we were not able to provide genetics to help clarify the taxonomic position of this unique coccidian species, which should be addressed in the future. We have assigned this species into the genus Goussia because of its epicellular nature in the intestine, apparent lack of a Stieda body, and requirement for exogenous sporulation, which are characteristics found most frequently in Goussia sp. In general, for coccidia in fish, considerable effort is required to better define the taxonomy of these abundant and diverse parasites. As more molecular sequences are obtained for fish coccidia, they will aid in understanding the taxonomic diversity and distribution of these parasites in fish hosts. Additionally, for $G$. echinata n. sp., more work is needed to establish the seasonal prevalence, intensity, and pathology associated with this intestinal coccidian.

Pathogen surveillance did not detect VHSV in any Atlantic herring sampled from New Jersey waters between 2013 and 2016. This should not be misinterpreted as an absence of the virus in the waters of New Jersey. Random samples of Pacific herring typically fail to return positive results (P. K. Hershberger unpubl.), even though the species is highly susceptible (Kocan et al. 1997) and epizootics occur frequently (Garver et al. 2013). Furthermore, VHSV-positive 
samples from Pacific herring are often not observed until after the capture and confinement of previously negative individuals (Hershberger et al. 1999, Lovy et al. 2013). A similar exacerbating factor may be required for the expression of VHSV in Atlantic herring populations, where low prevalence has previously been reported in North Sea, Baltic, and UK waters (Mortensen et al. 1999, King et al. 2001, Brudeseth \& Evensen 2002, Dixon et al. 2003, Matejusova et al. 2010). However, recent work by Johansen et al. (2013) investigating Atlantic herring from the Norwegian spring-spawning stock found prevalence as high as $69 \%$ when gill tissue was included in real-time RTPCR analyses, versus a $33 \%$ prevalence found in pooled brain, kidney, and spleen. This high prevalence, in the absence of disease signs, may indicate a passive carrier status rather than an active infection. Further explanation of the failure to detect VHSV may lie in the ability of fish to mount an immune response to the virus; Pacific herring surviving acute and sub-acute infections have demonstrated an adaptive immune response, which confers protection following re-exposure (Kocan et al. 2001, Hershberger et al. 2010b,c). Measuring the immune status of wild populations may help assess whether previous exposure has occurred and a present cycle of herd immunity may be protecting herring from epizootic events. Though VHSV has never been detected in New Jersey waters, strain IVc has been isolated from brackish water fishes from the Atlantic coastal regions of Canada (Gagné et al. 2007). As VHSV is typically found in coldwater environments, it is possible that the warm ocean currents associated with the Gulf Stream may contribute to the apparent lack of detections from New Jersey waters (Hershberger et al. 2013). The migratory behavior of Atlantic herring and their potential to harbor the virus actively or passively make this species a possible reservoir of VHSV in the North American Atlantic coast, and continued surveillance for this virus should identify if these populations may serve as a reservoir for the virus.

Perhaps more surprisingly, I. hoferi was not detected in any Atlantic herring during the current surveillance, even though the resulting disease has been responsible for epizootics on both sides of the Atlantic Ocean. Atlantic herring is recognized as a commonly infected species in the North Atlantic, and infection with $I$. hoferi is hypothesized to be an important factor limiting population growth (Sindermann 1990). Sindermann (1963) estimated that the Atlantic herring stock was reduced by at least $50 \%$ during a 1954-1956 outbreak of I. hoferi in the Gulf of St. Lawrence, whereas the Atlantic herring around
Denmark may have experienced mass mortality of 36\% during an epizootic in 1991 (Mellergaard \& Spanggaard 1997). Although $I$. hoferi was not detected in any samples from the current study, ongoing disease surveillance efforts are necessary for revealing possible threats to Atlantic herring populations. The absence of $I$. hoferi that we report in Atlantic herring is different from the pattern currently observed in populations of Pacific herring, where the parasite is typically observed in high prevalence, especially among older and larger age cohorts (Hershberger et al. 2016). Causes for these striking differences in infection prevalence between the 2 herring species remain uncertain but could be related to immunity or absence of the parasite. An analogous pattern occurs in American shad Alosa sapidissima, another clupeid, where a high prevalence of I. hoferi occurs in the NE Pacific (Hershberger et al. 2010a) and a low prevalence occurs along the Atlantic coast of North America (Gregg et al. 2016).

Detection of fish epizootics in the marine environment is typically limited to massive mortality events because quick dispersal by ocean currents, consumption by scavengers, and the vast size of marine water bodies prevent observations of dead fish. Diseases which produce chronic morbidity may lead to population declines that can easily go unnoticed. Monitoring important fish species for pathogens is useful for identifying diseases with the potential for populationlevel impacts.

Acknowledgements. We thank Gregory Hinks, Jason Hearon, and the NJDFW Bureau of Marine Fisheries. We are grateful for the assistance of the crew of the R/V 'Seawolf' and the R/V 'Zephyrus' in collecting fish samples for this study. We also thank the staff at the New Jersey Department of Agriculture, Animal Health Diagnostic Laboratory, particularly Denise Dicarlo-Emery, Lana Castellano, Sean Chadwick, Shannon Mann, Mala Ramachandra, and Wieslawa Wlaz, for their assistance in processing laboratory samples and Dr. Kyle Garver and the Herring Conservation and Research Society for providing Pacific herring and assisting with the project. This study was funded by the Federal Aid in Sport Fish Restoration Act, Project FW-69-R-18 (J. Lovy, Principal Investigator); the New Jersey Hunters and Anglers Fund; the 'Exxon Valdez' Oil Spill Trustee Council, Project 10100132-I; and the Fisheries Program of the Ecosystem Mission Area of the US Geological Survey. Any use of trade, firm or product names is for descriptive purposes only and does not imply endorsement by the U.S. Government.

\section{LITERATURE CITED}

Abollo E, Calvo M, Pascual S (2001) Hepatic coccidiosis of the blue whiting, Micromesistius poutassou (Risso), and horse mackerel, Trachurus trachurus (L.), from Galician waters. J Fish Dis 24:335-343 
Alvarez-Pellitero P, Sitjà-Bobadilla A (2002) Cryptosporidium molnari n. sp. (Apicomplexa: Cryptosporidiidae) infecting two marine fish species, Sparus aurata L. and Dicentrarchus labrax L. Int J Parasitol 32:1007-1021

$>$ Azevedo C (2001) Fine structure of sporogonic stages of Goussia clupearum (Apicomplexa: Eimeriidae) in the liver of infected fish (Belone belone L.), using light and electron microscopy. Parasitol Res 87:326-330

- Barta JR, Coles BA, Schito ML, Fernando MA, Martin A, Danforth HD (1998) Analysis of infraspecific variation among five strains of Eimeria maxima from North America. Int J Parasitol 28:485-492

$>$ Brudeseth BE, Evensen $\varnothing$ (2002) Occurrence of viral haemorrhagic septicaemia virus (VHSV) in wild marine fish species in the coastal regions of Norway. Dis Aquat Org 52:21-28

Burge CA, Eakin CM, Friedman CS, Froelich B and others (2014) Climate change influences on marine infectious diseases: implications for management and society. Annu Rev Mar Sci 6:249-277

Costa G, MacKenzie K (1994) Histopathology of Goussia clupearum (Protozoa: Apicomplexa: Coccidia) in some marine fish from Scottish waters. Dis Aquat Org 18: 195-202

> Dickey-Collas M, Nash RD, Brunel T, Van Damme CJ and others (2010) Lessons learned from stock collapse and recovery of North Sea herring: a review. ICES J Mar Sci 67:1875-1886

Dixon PF, Avery S, Chambers E, Feist S and others (2003) Four years of monitoring for viral haemorrhagic septicaemia virus in marine waters around the United Kingdom. Dis Aquat Org 54:175-186

$>$ Dyková I, Lom J (1981) Fish coccidia: critical notes on life cycles, classification and pathogenicity. J Fish Dis 4:487-505

Einer-Jensen K, Ahrens P, Forsberg R, Lorenzen N (2004) Evolution of the fish rhabdovirus viral haemorrhagic septicaemia virus. J Gen Virol 85:1167-1179

> Elsayed E, Faisal M, Thomas M, Whelan G, Batts W, Winton $\mathrm{J}$ (2006) Isolation of viral haemorrhagic septicaemia virus from muskellunge, Esox masquinongy (Mitchill), in Lake St Clair, Michigan, USA reveals a new sublineage of the North American genotype. J Fish Dis 29:611-619

> Emmenegger EJ, Moon CH, Hershberger PK, Kurath G (2013) Virulence of viral hemorrhagic septicemia virus (VHSV) genotypes Ia, IVa, IVb, and IVc in five fish species. Dis Aquat Org 107:99-111

FAO (Food and Agriculture Organization of the United Nations) (2014) State of world fisheries and aquaculture. FAO, Rome

Fournie JW, Overstreet RM (1983) True intermediate hosts for Eimeria funduli (Apicomplexa) from estuarine fishes. J Protozool 30:672-675

Fournie JW, Vogelbein WK, Overstreet RM, Hawkins WE (2000) Life cycle of Calyptospora funduli (Apicomplexa: Calyptosporidae). J Parasitol 86:501-505

> Gagné N, MacKinnon AM, Boston L, Souter B, Cook-Versloot M, Griffiths S, Olivier G (2007) Isolation of viral hemorrhagic septicemia virus from mummichog, stickleback, striped bass and brown trout in eastern Canada. J Fish Dis 30:213-223

> Garver KA, Traxler GS, Hawley LM, Richard J, Ross JP, Lovy J (2013) Molecular epidemiology of viral haemorrhagic septicaemia virus (VHSV) in British Columbia, Canada, reveals transmission from wild to farmed fish. Dis Aquat Org 104:93-104
Gestal C, Azevedo C (2005) Ultrastructure of Goussia cruciata (Apicomplexa: Coccidia) infecting the liver of horse mackerel, Trachurus trachurus (L.), from Ibero-Atlantic waters. J Fish Dis 28:125-132

Gibson-Kueh S, Thuy NTN, Elliot A, Jones JB, Nicholls PK, Thompson RCA (2011) An intestinal Eimeria infection in juvenile Asian seabass (Lates calcarifer) cultured in Vietnam - a first report. Vet Parasitol 181:106-112

- Gregg JL, Powers RL, Purcell MK, Friedman CS, Hershberger PK (2016) Ichthyophonus parasite phylogeny based on ITS DNA structure prediction and alignment identifies six clades, with a single dominant marine type. Dis Aquat Org 120:125-141

Hall TA (1999) Bioedit: a user-friendly biological sequence alignment editor and analysis program for Windows 95/98/NT. Nucleic Acids Symp Ser 41:95-98

Hay DE, Toresen RR, Stephenson R, Thompson M and others (2001) Taking stock: an inventory and review of world herring stocks in 2000. In: Funk F, Blackburn J, Day DH, Paul AJ, Stephenson R, Torresen R, Witherell D (eds) Herring expectation for a new millennium. Proceedings of the herring symposium 2000. Anchorage, AK, p 381-454

- Hershberger PK, Kocan RM, Elder NE, Meyers TR, Winton JR (1999) Epizootiology of viral hemorrhagic septicemia virus in Pacific herring from the spawn-on-kelp fishery in Prince William Sound, Alaska, USA. Dis Aquat Org 37:23-31

> Hershberger PK, Gregg J, Pacheco C, Winton J, Richard J, Traxler G (2007) Larval Pacific herring, Clupea pallasii (Valenciennes), are highly susceptible to viral hemorrhagic septicemia and survivors are partially protected after their metamorphosis to juveniles. J Fish Dis 30: 445-458

Hershberger PK, van der Leeuw BK, Gregg JL, Grady CA and others (2010a) Amplification and transport of an endemic fish disease by an invasive species. Biol Invasions 12:3665-3675

Hershberger PK, Gregg JL, Grady CA, Collins RM, Winton JR (2010b) Susceptibility of three stocks of Pacific herring to viral hemorrhagic septicemia. J Aquat Anim Health 22:1-7

> Hershberger PK, Gregg JL, Grady CA, Taylor L, Winton JR (2010c) Chronic and persistent viral hemorrhagic septicemia virus infections in Pacific herring. Dis Aquat Org 93:43-49

> Hershberger PK, Purcell MK, Hart LM, Gregg JL, Thompson RL, Garver KA, Winton JR (2013) Influence of temperature on viral hemorrhagic septicemia (Genogroup IVa) in Pacific herring, Clupea pallasii Valenciennes. J Exp Mar Biol Ecol 444:81-86

> Hershberger PK, Gregg JL, Hart LM, Moffitt S and others (2016) The parasite Ichthyophonus sp. in Pacific herring from the coastal NE Pacific. J Fish Dis 39:395-410

Johansen R, Bergh Ø, Modahl I, Dahle G, Gjerset B, Holst JC, Sandlund N (2013) High prevalence of viral haemorrhagic septicaemia virus (VHSV) in Norwegian springspawning herring. Mar Ecol Prog Ser 478:223-230

> Jonstrup SP, Kahns S, Skall HF, Boutrup TS, Olesen NJ (2013) Development and validation of a novel Taqmanbased real-time RT-PCR assay suitable for demonstrating freedom from viral haemorrhagic septicaemia virus. J Fish Dis 36:9-23

Kallert DM, Grabner DS, Yokoyama H, El-Matbouli M, Eszterbauer E (2015) Transmission of myxozoans to vertebrate hosts. In: Okamura B, Gruhl A, Bartholomew JL 
(eds) Myxozoan evolution, ecology and development. Springer, Cham, p 235-251

King JA, Snow M, Smail DA, Raynard RS (2001) Distribution of viral haemorrhagic septicaemia virus in wild fish species of the North Sea, north east Atlantic Ocean and Irish Sea. Dis Aquat Org 47:81-86

Kocan R, Bradley M, Elder N, Meyers T, Batts W, Winton J (1997) North American strain of viral hemorrhagic septicemia virus is highly pathogenic for laboratory-reared Pacific herring. J Aquat Anim Health 9:279-290

Kocan RM, Hershberger PK, Elder NE, Winton JR (2001) Epidemiology of viral hemorrhagic septicemia among juvenile Pacific herring and Pacific sand lances in Puget Sound, Washington. J Aquat Anim Health 13:77-85

Kumar S, Stecher G, Tamura K (2016) MEGA7: molecular evolutionary genetics analysis version 7.0 for bigger datasets. Mol Biol Evol 33:1870-1874

Lom J, Dyková I (1992) Protozoan parasites of fish. Elsevier Science Publishers, Amsterdam

> Lovy J, Friend SE (2015) Intestinal coccidiosis of anadromous and landlocked alewives, Alosa pseudoharengus, caused by Goussia ameliae n. sp. and G. alosii n. sp. (Apicomplexa: Eimeriidae). Int J Parasitol Parasites Wildl 4:159-170

> Lovy J, Piesik P, Hershberger PK, Garver KA (2013) Experimental infection studies demonstrating Atlantic salmon as a host and reservoir of viral hemorrhagic septicemia virus type IVa with insights into pathology and host immunity. Vet Microbiol 166:91-101

MacKenzie K (1979) Some parasites and diseases of blue whiting, Micromesistius poutassou (Risso), to the north and west of Scotland and at the Faroe Islands. Scot Fish Res Rep 17:1-14

MacKenzie K (1981) The effect of Eimeria sp. infection on the condition of blue whiting, Micromesistius poutassou (Risso). J Fish Dis 4:473-486

MacKenzie K (1987) Relationships between the herring, Clupea harengus L., and its parasites. Adv Mar Biol 24: 263-319

Marty GD, Freiberg EF, Meyers TR, Wilcock J, Farver TB, Hinton DE (1998) Viral hemorrhagic septicemia virus, Ichthyophonus hoferi, and other causes of morbidity in Pacific herring Clupea pallasi spawning in Prince William Sound, Alaska, USA. Dis Aquat Org 32:15-40

Marty GD, Hulson PJF, Miller SE, Quinn TJ, Moffitt SD, Merizon RA (2010) Failure of population recovery in relation to disease in Pacific herring. Dis Aquat Org 90:1-14

> Matejusova I, McKay P, Bland F, Snow M (2010) Application of a sensitive, specific and controlled real-time PCR assay to surveillance indicates a low prevalence of viral haemorrhagic septicaemia virus (VHSV) in wild herring, Clupea harengus L., in Scottish waters. J Fish Dis 33: 841-847

McAllister CT, Upton SJ (1989) The coccidia (Apicomplexa: Eimeriidae) of testudines, with descriptions of three new species. Can J Zool 67:2459-2467

Mellergaard S, Spanggaard B (1997) An Ichthyophonus hoferi epizootic in herring in the North Sea, the Skagerrak, the Kattegat and the Baltic Sea. Dis Aquat Org 28: 191-199

Melvin GD, Stephenson RL (2007) The dynamics of a recovering fish stock: Georges Bank herring. ICES J Mar Sci 64:69-82

> Meyers TR, Winton JR (1995) Viral hemorrhagic septicemia virus in North America. Annu Rev Fish Dis 5:3-24
Meyers TR, Short S, Lipson K, Batts WN, Winton JR, Wilcock J, Brown E (1994) Association of viral hemorrhagic septicemia virus with epizootic hemorrhages of the skin in Pacific herring Clupea harengus pallasi from Prince William Sound and Kodiak Island, Alaska, USA. Dis Aquat Org 19:27-37

Molnár K, Ostoros G, Baska F (2005) Cross-infection experiments confirm the host specificity of Goussia spp. (Eimeriidae: Apicomplexa) parasitizing cyprinid fish. Acta Protozool 44:43-49

Molnár K, Ostoros G, Dunams-Morel D, Rosenthal BM (2012) Eimeria that infect fish are diverse and are related to, but distinct from, those that infect terrestrial vertebrates. Infect Genet Evol 12:1810-1815

> Morrison CM, Hawkins WE (1984) Coccidians in the liver and testis of the herring Clupea harengus L. Can J Zool 62:480-493

Morrison CM, Marryatt VM (1990) Coccidia found in some marine finfish off Nova Scotia. In: Perkins FO, Cheng TC (eds) Pathology in marine science. Academic Press, San Diego, CA, p 165-174

> Mortensen HF, Heuer OE, Lorenzen N, Otte L, Olesen NJ (1999) Isolation of viral haemorrhagic septicaemia virus (VHSV) from wild marine fish species in the Baltic Sea, Kattegat, Skagerrak and the North Sea. Virus Res 63: 95-106

Nei M, Kumar S (2000). Molecular evolution and phylogenetics. Oxford University Press, New York, NY

- Overstreet RM, Hawkins WE, Fournie JW (1984) The coccidian genus Calyptospora n.g. and family Calyptosporidae n. fam. (Apicomplexa), with members infecting primarily fishes. J Protozool 31:332-339

> Phelps NB, Patnayak DP, Jiang Y, Goyal SM (2012) The use of a one-step real-time reverse transcription polymerase chain reaction (rRT-PCR) for the surveillance of viral hemorrhagic septicemia virus (VHSV) in Minnesota. J Aquat Anim Health 24:238-243

> Pierce LR, Stepien CA (2012) Evolution and biogeography of an emerging quasispecies: diversity patterns of the fish viral hemorrhagic septicemia virus (VHSV). Mol Phylogenet Evol 63:327-341

Rahimian H, Thulin J (1996) Epizootiology of Ichthyophonus hoferi in herring populations off the Swedish west coast. Dis Aquat Org 27:187-195

Richardson DE, Hare JA, Fogarty MJ, Link JS (2011) Role of egg predation by haddock in the decline of an Atlantic herring population. Proc Natl Acad Sci USA 108: 13606-13611

Rosenthal BM, Molnár K, Dunams-Morel D, Ostoros G (2016) Coccidian parasites of fish encompass profound phylogenetic diversity and gave rise to each of the major parasitic groups in terrestrial vertebrates. Infect Genet Evol 40:219-227

Sindermann CJ (1963) Disease in marine populations. Trans North Am Wildl Conf 28:336-356

Sindermann CJ (1990) Principal diseases of marine fish and shellfish, Vol 1, 2nd edn. Academic Press, New York, NY

Sindermann CJ, Chenoweth JF (1993) The fungal pathogen Ichthyophonus hoferi in sea herring Clupea harengus: a perspective from the western North Atlantic. ICES CM 1993/F:41

Široký P, Modrý D (2006) Two eimerian coccidia (Apicomplexa: Eimeriidae) from the critically endangered Arakan forest turtle Heosemys depressa (Testudines: Geoemydi- 
dae) with description of Eimeria arakanensis n. sp. Acta Protozool 45:183-189

Široký P, Kamler M, Modrý D (2006) A new Eimeria (Apicomplexa: Eimeriidae), possessing mitra-shaped oocysts, from the Neotropical chelid turtle Batrachemys heliostemma (Testudines: Chelidae), and its comparison with Eimeria mitraria (Laveran \& Mesnil 1902). Mem Inst Oswaldo Cruz 101:555-558

Sitjà-Bobadilla A, Alvarez-Pellitero P (2003) Experimental transmission of Cryptosporidium molnari (Apicomplexa: Coccidia) to gilthead sea bream (Sparus aurata L.) and European sea bass (Dicentrarchus labrax L.). Parasitol Res 91:209-214

Skall HF, Olesen NJ, Mellergaard S (2005) Viral haemorrhagic septicaemia virus in marine fish and its implications for fish farming - a review. J Fish Dis 28:509-529

Székely C, Borkhanuddin MH, Shaharom F, Embong MSA, Molnar K (2013) Description of Goussia kuehae

Editorial responsibility: Catherine Collins,

Aberdeen, UK n. sp. (Apicomplexa: Eimeriidae) infecting the Asian seabass, Lates calcarifer (Bloch) (Perciformes: Latidae), cultured in Malaysian fish farms. Syst Parasitol 86: 293-299

Warg JV, Clement T, Cornwell ER, Cruz A and others (2014) Detection and surveillance of viral hemorrhagic septicemia virus using real-time RT-PCR. II. Diagnostic evaluation of two protocols. Dis Aquat Org 111:15-22

Whipps CM, Fournie JW, Morrison DA, Azevedo C, Matos E, Thebo P, Kent ML (2012) Phylogeny of fish-infecting Calyptospora species (Apicomplexa: Eimeriorina). Parasitol Res 111:1331-1342

White TJ, Bruns T, Lee S, Taylor J (1990) Amplification and direct sequencing of fungal ribosomal RNA genes for phylogenetics. In: Innis MA, Gelfand DJ, Sninsky JJ, White TJ (eds) PCR protocols: a guide to methods and applications. Academic Press, San Diego, CA, p 315-322

Submitted: November 16, 2015; Accepted: May 4, 2016 Proofs received from author(s): June 29, 2016 